\title{
RANCANG BANGUN ALAT PEMOTONG/PENGIRIS BAHAN BAKU KRUPUK TERIGU DAN KRIPIK SINGKONG
}

\author{
I.M. Widiyarta ${ }^{1}$, D.N.K.P. Negara ${ }^{2}$ dan I.D.M.K. $\mathrm{Muku}^{3}$
}

\begin{abstract}
ABSTRAK
Usaha mikro krupuk terigu dan kripik singkong merupakan usaha rumahan yang banyak digeluti beberapa keluarga di Kabupaten Buleleng dan Karangasem. Dalam usaha rumahan tersebut, umumnya mereka menhadapi permasalahan yang relatif sama, yaitu effisiensi dan produktifitas yang relatif rendah. Permasalahan ini disebabkan pada bagian proses pemotongan/pengirisan bahan baku kerupuk terigu dan singkong yang masih konvensional sehingga membutuhkan waktu yang lama.

Pada artikel ini, mesin pengiris bahan kripik singkong dan krupuk terigu dibuat dengan kecepatan potong mencapai 120 potong/menit. Mesin memiliki tiga bagian utama yaitu bagian penggerak dengan memanfaatkan motor DC $0.25 \mathrm{Hp}$, bagian pengiris berupa pisau disk dan bagian pengarah bahan baku kripik/krupuk yang akan diiris.
\end{abstract}

Kata Kunci : usaha mkro, alat potong/iris, krupuk terigu, kripik singkong.

\begin{abstract}
Micro business of wheat flour chips and cassava chips is a home business that many families do in Buleleng and Karangasem regency. In that home-based business, they are generally facing the similar problems such as relatively low of efficiency and productivity. These problems are caused in the process of cutting or slicing raw material of chips that is still processed conventionally so it takes a long time.

In this article, the slicing machine of chips is designed with cutting speed reaches of about 120 pieces/minute. The machine has three main parts such as the driving part of $0.25 \mathrm{Hp}$ DC-Motor, the slicing section with disk knife and guide section of sliced chips.
\end{abstract}

Keywords: Micro business, cutting/slicing machine, wheat flour chip, cassava chips.

\section{PENDAhuluan}

Kerupuk merupakan produk makanan kering yang popular yang telah lama dikenal masyarakat Indonesia. Produk ini sangat digemari oleh masyarakat sebagai sebutan cemilan dan memiliki prospek yang cukup menjanjikan. Cemilan kerupuk terigu banyak dikonsumsi sebagai pelengkap ketika menyantap nasi atau dikonsumsi sebagai pendamping ketika minum kopi. Jenis produk krupuk ini banyak diproduksi dan digeluti dalam industry kecil atau industri rumah tangga di berbagai daerah di Bali, seperti di Kabupaten Karangasem dan Buleleng.

\footnotetext{
${ }^{1}$ Staf Pengajar Jurusan Teknik Mesin Fakultas Teknik Universitas Udayana, m.widiyarta@unud.ac.id

${ }^{2}$ Staf Pengajar Jurusan Teknik Mesin Fakultas Teknik Universitas Udayana, devputranegara@gmail.com

${ }^{3}$ Staf Pengajar Jurusan Teknik Mesin Fakultas Teknik Universitas
} 
Industri kecil ini banyak dilakukan oleh ibu rumah tangga, dimana dalam menjalankan usaha mikro krupuk terigu ini umumnya dilakukan disela rutinitas keseharian mereka mengurusi keperluan keluarga. Aktifitas pembuatan kerupuk terigu ini dilakukan secara sederhana dan menggunakan peralatan yang sangat sederhana pula. Secara umum proses pembuatan kerupuk terigu yang dilakukan ditunjukkan seperti Gambar 1. Dapat dilihat bahwa pembuatan krupuk terigu terdiri dari proses persiapan bahan, pencampuran, pemadatan (pembuatan gelondongan), pengirisan, penjemuran, penggorengan dan pengemasan. Dari keseluruhan proses tersebut, tahapan proses pemotongan/pengirisan membutuhkan waktu yang relative cukup lama karena dikerjakan secara manual, sehingga untuk mendapatkan irisan yang tipis dan relative sama dibutuhkan kesabaran. Sebagai suatu gambaran, untuk $1 \mathrm{Kg}$ bahan baku dapat dihasilkan rata-rata 8 buah gelondongan (Gelondongan adalah bahan baku kerupuk terigu yang sudah padat dan siap untuk diiris/dipotong). Satu gelondongan memiliki panjang kurang lebih $8 \mathrm{~cm}$ dengan diameter $6 \mathrm{~cm}$. Pengirisan satu gelondongan memerlukan waktu pemotongan/pengirisan kurang lebih 6 menit, sehingga untuk $1 \mathrm{~kg}$ bahan baku dibutuhkan waktu sekitar 48 menit. Hal ini sangatlah tidak effisien. Sementara karena pengerjaannya dilakukan di sela-sela kesibukannya sebagai ibu rumah tangga, perharinya hanya mampu dibuat $1-2 \mathrm{~kg}$ sedangkan permintaan pasar dapat mencapai $5-6 \mathrm{~kg}$ per hari.

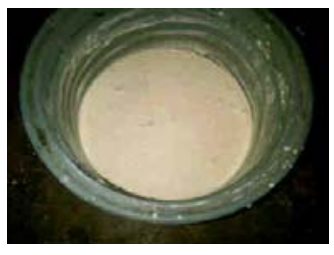

a

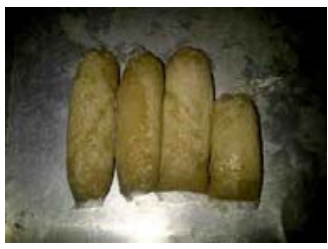

e

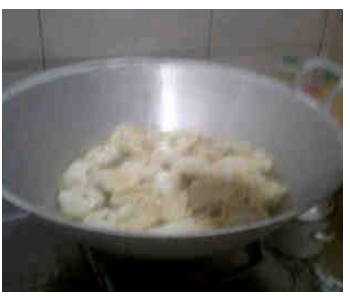

i

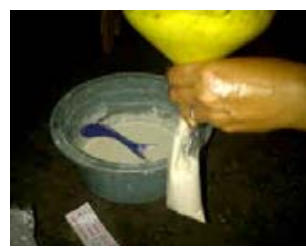

b

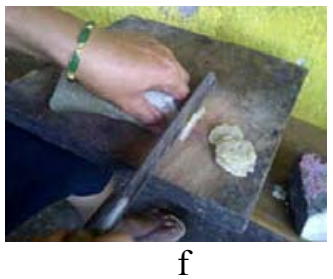

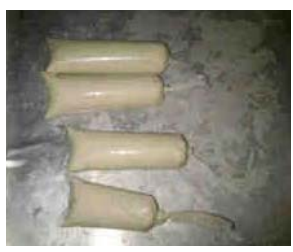

C

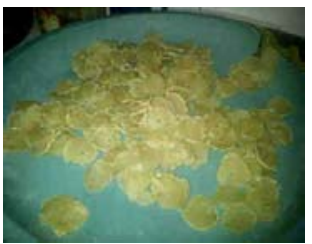

g

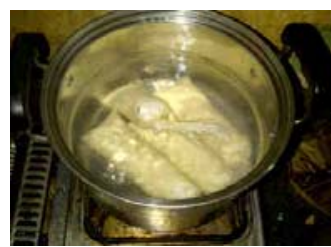

d

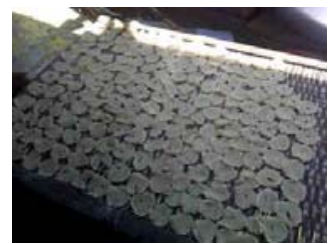

$\mathrm{h}$

Gambar 1. Proses pembuatan krupuk terigu; a. Pencampuran bahan baku menjadi bubur; b. Bubur bahan baku dimasukkan ke kantung plastic; c. Bubur yang sudah berada di dalam plastic; d. Bubur dalam plastik direbus agar mengental; e. Bubur dalam plastik yang sudah mengental (menjadi gelondongan); f. Proses pengirisan/pemotongan; g. Irisan dijemur; $h$.

Irisan yang sudah kering siap digoreng; i. Proses penggorengan; j. Krupuk yang sudah tergoreng; k. Pengemasan

Melihat kondisi ini, dalam penelitian ini, maka dilakukan perancangan mesin pengiris gelondongan krupuk/singkong semi otomatis yang digerakkan dengan motor listrik. Mesin dirancang dengan mekanisme yang sederhana sehingga sangat mudah untuk dioperasikan. Mesin tediri dari tiga 
bagian utama yaitu bagian penggerak menggunakan motor DC, bagian pemotong/pengiris menggunakan pisau potong yang diletakkan pada disk dan bagian pengarah bahan baku yang akan dipotong.

\section{METODE PELAKSANAAN}

Perancangan dan pembuatan mesin potong/iris bahan baku kerupuk/keripik secara umum dibagi menjadi tiga tahapan utama seperti ditunjukkan pada Gambar 2 (Atila, 1993; Karl, 2001; Khurmi, 2005). Pengamatan lapangan ditujukan untuk mengidentifikasi dan memahami kebutuhan dalam proses dan bagian dari proses yang dapat dikembangkan. Bagian perancangan dan pembuatan alat meliputi kegiatan penentuan mekanisme kerja alat, analisa dan pemilihan material/komponen, menggambar alat termasuk detail komponennya, dan pembuatan alat. Pada bagian akhir dilakukan uji kelayakan/kapasitas alat untuk memastikan alat dapat berfungsi dengan baik dan dapat berproduksi sesuai dengan kapasitas yang diinginkan.

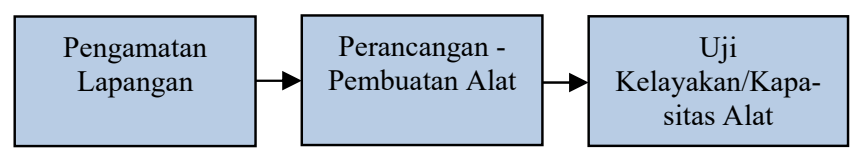

Gambar 2. Bagan alur pembuatan mesin potong

Mesin potong/iris bahan baku kripik/kerupuk seperti pada Gambar 3 dirancang dengan system penggerak menggunakan motor DC, system transmisi menggunakan v-belt dan pulley dan dengan pisau potong/iris pada disk. Bahan baku yang akan dipotong diarahkan melalui pengarah bahan baku.

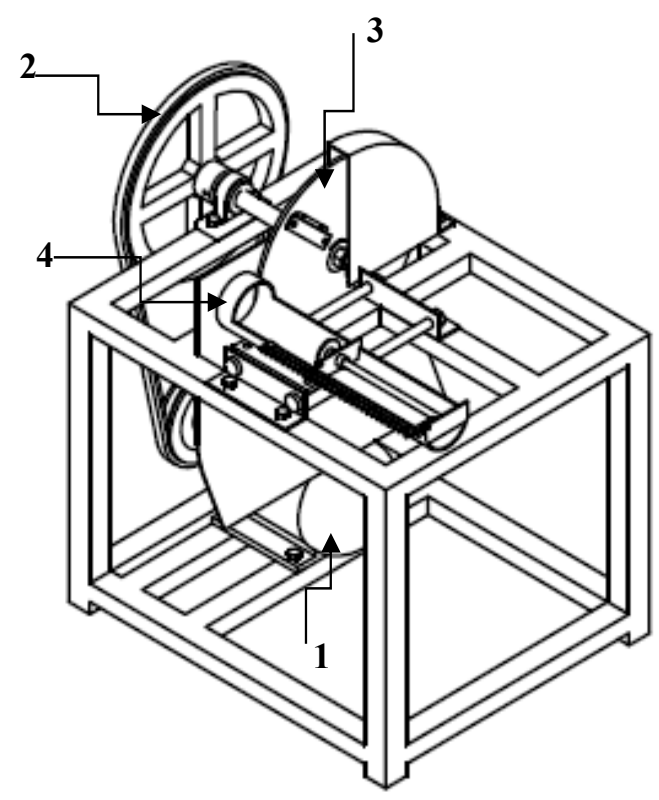

Gambar 3. Mesin potong/iris kripik; 1. Motor DC; 2. Sistem transmisi; 3. Disk/pisau iris; 4.

Pengarah bahan baku. 
Prinsip kerja dari mesin dapat dijelaskan sebagai berikut. Daya dari motor ditransmisikan melalui belt yang dikaitkan pada pulley. Pada poros pulley tersebut dipasang disc yang dilengkapi dua mata potong yang berfungsi sebagai pengiris. Untuk sistem pengirisannya menggunakan sistem putaran roda (rotasi), sehingga satu putaran roda bisa mengiris dua kali dengan kecepatan putar roda 60 r.p.m. Jika dibuat suatu perbandingan produktifitas dan hitungan ekonomis dari pengirisan secara konvensional dan dengan menggunakan alat pengiris yang direncanakan dapat digambarkan sebagai berikut. Satu kg bahan baku menghasilkan 8 gelondongan. Satu gelondongan (rata-rata 8 $\mathrm{cm}=80 \mathrm{~mm}$ ) dipotong kecil-kecil per $2 \mathrm{~mm}$ menghasilkan $80 / 2=40$ potong krupuk mentah diselesaikan dalam 6 menit secara konvensional. Untuk 8 gelondongan dibutuhkan waktu 48 menit. Dengan menggunakan alat potong ini satu gelondongan dapat diselesaikan hanya dengan waktu $80 /(60 \times 2)=0.666$ menit atau $0.666 \times 60$ detik $=40$ detik, maka untuk 8 gelontongan dapat diselesaikan dengan waktu lebih kurang $8 \times 40$ detik $=320$ detik $=320 / 60=5,33$ menit. Bila ditambah dengan waktu penyetingan selama 2,5 menit, total waktu yang dibutuhkan sekitar 7,83 menit (dibulatkan menjadi 8 menit) sehingga diperoleh peningkatan kapasitas produksi dan effisiensi waktu mencapai 6 kalinya.

\section{HASIL DAN PEMBAHASAN}

Hasil rancangan mesin potong/iris bahan baku kripik/kerupuk dapat dilihat pada Gambar 4. Prinsip kerja dari mesin dapat dijelaskan sebagai berikut, daya dari motor ditransmisikan melalui belt yang dikaitkan pada pulley. Pada poros pulley tersebut dipasang disk yang dilengkapi dua pisau potong yang berfungsi sebagai pemotong/pengiris. Untuk sistem pengirisannya menggunakan sistem putaran roda (rotasi), sehingga satu putaran roda bisa mengiris dua kali dengan kecepatan putar disk 60 r.p.m., atau sama dengan kapasitas potong 120 potong/menit.

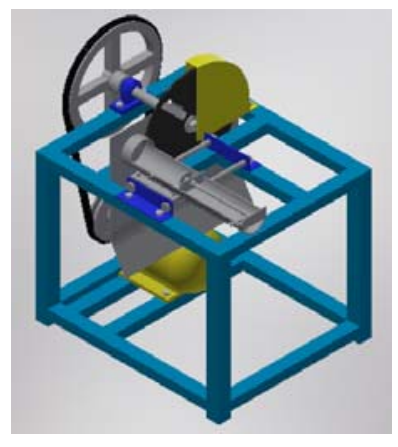

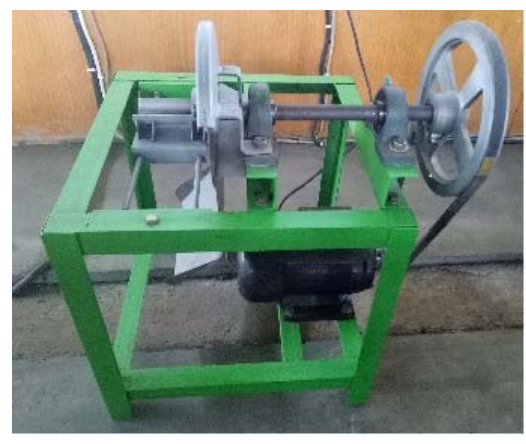

$\mathrm{b}$

Gambar 4 a) Gambar disain, b) Alat potong/iris bahan baku kripik/kerupuk

Hasil uji menunjukkan mesin potong/iris dapat berfungsi dengan baik. Dengan menggunakan alat potong/iris semi otomatis pengganti proses pemotongan/pengirisan bahan baku krupuk/kripik dengan cara manual yaitu, waktu produksi dapat dipersingkat, ukuran hasil potongan dapat lebih seragam (Gambar 5), pekerja setelah selesai proses pengirisan dapat mengerjakan proses yang lain. 


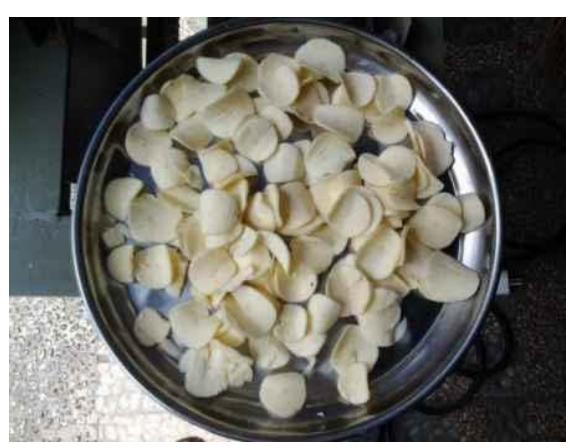

Gambar 5. Hasil irisan bahan kripik

\section{HASIL DAN PEMBAHASAN}

Dari hasil perancangan, mesin pengiris bahan kripik singkong dan krupuk terigu memiliki kecepatan disk pisau potong 60 putaran/menit atau sama dengan kecepatan potong 120 potongan/menit. Uji kelayakan mesin potong/iris bahan baku kripik/kerupuk menunjukkan alat dapat berfungsi dengan baik dan ukuran hasil potongan relative seragam.

\section{UCAPAN TERIMAKASIH}

Terima kasih penulis ucapkan kepada Kementerian Riset, Teknologi dan Pendidikan Tinggi (RISTEKDIKTI) atas bantuan pendanaan melalui Hibah IbM (Ipteks bagi Masyarakat) tahun 2017.

\section{DAFTAR PUSTAKA}

Atila Ertas, Jesse C. Jones, 1993, The Engineering Design Process, John Wiley \& Sons, Inc, New York.

Karl T. Ulrich, Steven D. Eppinger, 2001, Perancangan dan Pengembangan Produk, Salemba Teknika, Jakarta.

Khurmi R.S., Gupta J.K., 2005, The Textbook of Machine Design, $1^{\text {st }}$ Addition, Euraasia Publishing House (PVT.) LTD 